\title{
Aktualisasi Welfare State Terhadap Kehidupan Bernegara Dalam Dimensi Keislaman dan Keindonesiaan*
}

\section{(ACTUALIZATION WELFARE STATE AGAINST THE LIFE OF STATELESS IN DIMENSIONS ISLAMIC AND INDONESIAAN)}

\author{
Nur Rohim Yunus \\ Fakultas Syariah dan Hukum UIN Jakarta \\ Jl. Ir. H. Juanda No. 95 Ciputat Tangsel \\ Email: nurrohimyunus@uinjkt.ac.id
}

\begin{abstract}
Every state must have the goal the welfare of its citizens, as the slogan of the Welfare State. In the implementation of the Welfare State is based on the principle of equality of opportunity, equitable distribution of wealth, and the public responsibility against those who are not able to supply its own needs. This means that the state is directly involved in the affairs of its citizens, so no experience discrimination in social life. Including the state of Indonesia, making the welfare state as a slogan in order to achieve social justice for all Indonesian people.
\end{abstract}

Keywords: Welfare State, state, welfare

\begin{abstract}
Abstrak: Setiap negara wajib memiliki tujuan menyejahterakan warganya sebagaimana slogan Welfare State. Dalam pelaksanaannya Welfare State didasarkan pada prinsip persamaan kesempatan (equality of opportunity), pemerataan pendapatan (equitable distribution of wealth), dan tanggung jawab publik (public responsibility) terhadap mereka yang tidak mampu untuk menyediakan sendiri kebutuhan. Artinya negara terlibat langsung dalam urusan warga negaranya, sehingga tidak ada yang mengalami diskriminasi dalam kehidupan sosialnya. Termasuk negara Indonesia, menjadikan welfare state sebagai slogan guna mencapai tujuan keadilan sosial bagi seluruh rakyat Indonesia.
\end{abstract}

Kata Kunci: Welfare State, bernegara, kesejahteraan

\footnotetext{
* Diterima tanggal naskah diterima: 24 Juni 2015, direvisi: 11 Agustus 2015, disetujui untuk terbit: 16 Oktober 2015.
} 


\section{Pendahuluan}

Negara Indonesia seringkali disebut sebagai negara yang mengusung gagasan Negara kesejahteraan (welfare State). Hal ini karena di dalam pembukaan UUD NRI 1945 terdapat salah satu tujuan negara yang mengekspresikan gagasan negara kesejahteraan. Dalam istilah umum, sejahtera menunjuk kepada keadaan yang baik, pada kondisi manusia di mana orang-orangnya dalam keadaan makmur, dalam keadaan sehat dan damai, dalam kebijakan sosial, kesejahteraan sosial, menunjuk kepada jangkauan pelayanan untuk memenuhi kebutuhan masyarakat. Istilah inilah yang digunakan dalam ide negara sejahtera.

Kesejahteraan berkaitan erat pula dengan keadilan. Sedang keadilan adalah kata sifat yang artinya sifat yang adil, tidak berat sebelah. Keadilan berhubungan erat dengan tingkah laku yang dapat diterima dalam sebuah komunitas yang menjamin rasa percaya antara satu terhadap yang lain, yang tidak dapat dinilai dengan materi, tetapi dengan nurani yang manusiawi.

Pada ranah kenegaraan yang perlu diketahui adalah bagaimana menjadikan masyarakat sejahtera dan makmur, tanpa melepaskan sendi-sendi keutamaan sebuah negara itu berdiri. Negara hukum dan pemerintahan yang demokrasi adalah persyaratan yang urgen dalam pembangunan sebuah negara dan menjadikannya lebih jelas dari tipe sejarah maupun dari kacamata hukum.

Konsep Negara Kesejahteraan yang lahir diera abad ke-20 sebagai koreksi berkembangnya konsep Negara 'Penjaga Malam' (nachtwachtersstaat), muncul pula gejala kapitalisme di lapangan perekonomian yang secara perlahan-lahan menyebabkan terjadinya kepincangan dalam pembagian sumber-sumber kemakmuran bersama. Akibatnya timbul jurang kemiskinan yang menunjukan kecenderungan semakin menajam, yang sulit dipecahkan oleh negara yang difungsikan secara minimal.

Negara dianggap tidak dapat melepaskan tanggung jawabnya untuk meningkatkan kesejahteraan masyarakat. Karenanya muncul kesadaran baru mengenai pentingnya keterlibatan negara dalam menangani dan mengatasi masalah ketimpangan kehidupan sosial masyarakat. Pemerintah sebagai pihak yang memiliki tanggungjawab terhadap keadaan warga negaranya termasuk dalam kesejahteraan. Karenanya ciri utama dari konsep negara ini adalah adanya kewajiban negara untuk mewujudkan kesejahteraan umum. 
Artinya, negara berhak bahkan wajib untuk ikut campur dalam kehidupan masyarakat sebagai langkah untuk mewujudkan kesejahteraan umum. ${ }^{1}$

Di sisi lain, muncul pula aliran sosialisme yang sangat menentang individualisme dan liberalisme yang dianggap sebagai sebab munculnya kapitalisme yang menindas rakyat miskin bahkan menciptakan kemiskinan itu sendiri. Karena itu, atas pengaruh sosialisme ini, muncul konsepsi baru mengenai negara sejak permulaan abad ke-20 ini sebagai ganti dari 'Nachwachtersfaaf', yaitu 'Welvaarstaat'/'Welfare State' (Negara Kesejahteraan). ${ }^{2}$

Welfare state atau yang lazim disebut sebagai negara sejahtera merupakan gagasan ideal bagaimana suatu negara melaksanakan tugasnya dalam rangka untuk melayani warga negara menuju tatanan kehidupan yang harmonis dan sejahtera. Dengan demikian, pada dasarnya keberadaan konsep walfare state tidak dapat dipisahkan dari sistem politik-ekonomi yang berkembang yang dalam hal ini adalah sistem kapitalisme, ${ }^{3}$ sosialisme, dan Islam.

Dalam konsep negara kesejahteraan, negara dituntut untuk memperluas tanggung jawabnya kepada masalah-masalah sosial ekonomi yang dihadapi rakyat banyak. Perkembangan inilah yang memberikan legalisasi bagi 'negara intervensionis' abad ke-20. Fungsi Negara juga meliputi kegiatan-kegiatan yang sebelumnya berada di luar jangkauan fungsi negara, seperti memperluas ketentuan pelayanan sosial kepada individu dan keluarga dalam hal-hal khusus, seperti 'social security', kesehatan, kesejahteraan-sosial, pendidikan dan pelatihan serta perumahan.

1Juniarso Ridwan \& Ahmad Sodik Sudrajat, Hukum Administrasi Negara dan Kebijakan Pelayan Publik, (Bandung: Nuansa , 2009) hal: 56

${ }^{2}$ Miriam Budiardjo, Dasar-dasar ilmu politik, (Jakarta: Gramedia Pustaka Utama, 2001), h. 52

${ }^{3}$ Kapitalisme sebagai sistem ekonomi modern yang pertama kali diperkenalkan oleh manusia hadir dengan gagasan welfare state yang menjunjung kebebasan individu. Hal ini merupakan bentuk manifestasi atau teori Invisible Hand Adam Smith yang menghendaki akan minimnya peran serta negara dalam interaksi ekonomi. Teori tersebut pada dasarnya menyatakan jika setiap individu diberikan kebebasan untuk mengembangkan modal yang dimilikinnya tanpa adanya campur tangan negara, maka ia akan mampu mewujudkan kesejahteraan di lingkungan sekitarnya. [Lihat: Suherman Rosydi, Pengantar Teori Ekonomi: pendekatan Kepada Teori Ekonomi Mikro dan Teori Ekonomi Makro, (Jakarta: PT. Raja Grafindo Persada, 1998), h. 16-17]. 


\section{Pengertian Welfare State}

Konsep Negara Kesejahteraan (Welfare State) tidaklah asing di kalangan ahli hukum, ekonomi, dan politik. Namun karena luasnya cakupan maka kajian hukum akan berbeda dari kajian ekonomi dan politik tentang apa Welfare State itu. Setidaknya ada beberapa pandangan yang berbeda tentang konsep Welfare State sebagaimana yang terjadi di berbagai Negara.

Definisi Welfare State dalam Black's Law Dictionary menyebutkan:

Negara Kesejahteraan adalah suatu bangsa yang pemerintahnya menjalankan berbagai program asuransi sosial, seperti kompensasi pengangguran, pensiun, bantuan uang untuk keluarga, kupon makanan, dan bantuan bagi orang buta atau tuli juga pengertian kesejahteraan-negara sebagai pengatur. ${ }^{4}$

Definisi Welfare State dalam "Collin colbuid English Dictionary" sebagaimana dikutip Safri Nugraha menyebutkan:

“Negara Kesejahteraan adalah suatu sistem pemerintahan yang menyediakan pelayanan sosial secara gratis (bebas biaya) dalam hal: kesehatan, pendidikan, dan bantuan keuangan bagi warga yang tidak mampu bekerja karena usia lanjut, pengangguran atau sakit."

Dari dua definisi tersebut dapat disimpulkan, bahwa welfare state adalah suatu pemerintahan negara yang mengatur sekaligus menjalankan tugas berkaitan dengan pemenuhan kebutuhan dasar hidup manusia (basic needs), perumahan, pendidikan, makanan, pakaian, pekerjaan, dan pelayanan sosial: santunan keuangan bagi para pensiun, orang tua, sakit, serta orangorang penyandang penyakit sosial: buta, tuli.

Welfare state adalah tanggung jawab negara terhadap kesejahteraan warganya, sebagaimana dalam Encyclopedia Britannica, welfare state diartikan sebagai konsep pemerintahan dimana negara memainkan peran kunci dalam menjaga dan memajukan kesejahteraan ekonomi dan sosial warga negaranya. ${ }^{5}$ Sedangkan the Concise Oxford Dictionary of Politics mendefinisikannya sebagai sebuah sistem dimana pemerintah menyatakan diri bertanggung jawab untuk menyediakan jaminan sosial dan ekonomi bagi penduduk melalui sarana

${ }^{4}$ Black's Law Dictionary Online, diunduh pada tanggal 26 september 2013 pukul 16.00

5“Welfare State”, Encyclopedia Britannica, http://www.britannica.com/print/topic/639266 (diakses 22 Sep. 14). 
pensiun, tunjangan jaminan sosial, layanan kesehatan gratis dan semacamnya. ${ }^{6}$

Menurut Paul Spicker, Negara kesejahteraan adalah upaya untuk melepaskan diri dari stigma undang-undang Miskin. Itu tidak dirancang untuk masyarakat miskin; itu seharusnya menawarkan perlindungan sosial bagi semua orang, untuk mencegah orang dari menjadi miskin. ${ }^{7}$

Welfare state diasosiasikan dengan pemenuhan kebutuhan dasar. Oleh karena itu, ia dianggap sebagai mekanisme pemerataan terhadap kesenjangan yang ditimbulkan oleh ekonomi pasar. Jaminan sosial, kesehatan, perumahan dan pendidikan adalah wilayah garapan utama dari kebijakan pemerintah yang menganut welfare state.

Program pengentasan kemiskinan dan sistem perpajakan juga dianggap sebagai aspek dari welfare state. Alasan dimasukkannya perpajakan ke dalam kategori sifat welfare state adalah jika penarikan pajak bersifat progresif dan dananya digunakan untuk mencapai distribusi pendapatan yang lebih besar dan bukan hanya sekedar untuk meningkatkan pendapatan negara. Di samping itu, dana pajak tersebut juga digunakan untuk membiayai pembayaran asuransi sosial dan manfaat-manfaat lainnya yang belum dicakup oleh pembayaran premi asuransi sosial. Di negara-negara sosialis, welfare state juga meliputi jaminan pekerjaan dan administrasi harga barang dan jasa pada level konsumen (consumer prices). Konsep Welfare State biasanya didasarkan pada prinsip persamaan kesempatan (equality of opportunity), pemerataan pendapatan (equitable distribution of wealth), dan tanggung jawab publik (public responsibility) terhadap mereka yang tidak mampu untuk menyediakan sendiri kebutuhan. ${ }^{8}$

Konsep kesejahteraan (welfare) memang sering diartikan berbeda oleh banyak orang dan negara yang berbeda. Merujuk pada Spicker (1995), Midgley, Tracy dan Livermore (2000), Thompson (2005), Suharto, (2005a), dan

${ }^{6}$ Ed Iain McLean and Alistair McMillan. MC "welfare state" The Concise Oxford Dictionary of Politics. Oxford University Press 2009. Oxford Reference Online. Oxford University Press. University of Washington, http://www.oxfordreference.com.offcampus.lib.washington.edu/views/ENTRY. html?subview=Main\&entry=t86.e1462 (diakses 22 Sep. 14).

7 Paul Spicker, Poverty and the Welfare State: Dispelling the Myths, (London: Catalyst, 2002), h. 6

${ }^{8}$ Alfitri, ideologi Welfare State dalam Dasar negara indonesia, Jurnal Konstitusi Volume 9 Nomor 3 (jakarta: Mahkamah Konstitusi, 2012), h. 454. 
Suharto (2006), pengertian kesejahteraan sedikitnya mengandung empat makna.

Pertama; Sebagai kondisi sejahtera (well-being). Pengertian ini biasanya menunjuk pada istilah kesejahteraan sosial (social welfare) sebagai kondisi terpenuhinya kebutuhan material dan non-material. Midgley ${ }^{9}$ mendefinisikan kesejahteraan sosial sebagai "... a condition or state of human well-being." Kondisi sejahtera terjadi manakala kehidupan manusia aman dan bahagia karena kebutuhan dasar akan gizi, kesehatan, pendidikan, tempat tinggal, dan pendapatan dapat dipenuhi; serta manakala manusia memperoleh perlindungan dari resiko-resiko utama yang mengancam kehidupannya.

Kedua; Sebagai pelayanan sosial. Di Inggris, Australia dan Selandia Baru, pelayanan sosial umumnya mencakup lima bentuk, yakni jaminan sosial (social security), pelayanan kesehatan, pendidikan, perumahan dan pelayanan sosial personal (personal social services).

Ketiga; Sebagai tunjangan sosial. Khususnya di Amerika Serikat (AS), diberikan kepada orang miskin. Karena sebagian besar penerima welfare adalah orang-orang miskin, cacat, penganggur, keadaan ini kemudian menimbulkan konotasi negatif pada istilah kesejahteraan, seperti kemiskinan, kemalasan, ketergantungan, yang sebenarnya lebih tepat disebut "social illfare" ketimbang "social welfare".

Keempat; Sebagai proses atau usaha terencana. Hal ini baik dilakukan oleh perorangan, lembaga-lembaga sosial, masyarakat maupun badan-badan pemerintah untuk meningkatkan kualitas kehidupan melalui pemberian pelayanan sosial dan tunjangan sosial. ${ }^{10}$

Istilah walfare state dipersamakan dengan the caring state oleh van Caenegem. Sehubungan dengan makna welfare state tersebut dikatakan oleh Caenegem:

"The caring state or welfare state does not see its not only role in creation of a legal framework for flouring laissez-faire, but wants to intervene in economic life, create or at least stimulate prosperity, distribute equally and provide for everyone an existence that is not only legally but also economically safe. It is, however, clear that if the state is supossed to look after everything and

\footnotetext{
${ }^{9}$ Midgley, et al (2000), h. xi

${ }^{10}$ Edi Suharto, Welfare State, 2006, h. 2-3
} 
everyone, everybody will come to depend on the state and its political and bureaucrati elites. ${ }^{11}$

Para ahli yang lain pun menjelaskan mengenai apa itu walfare state:

1. Spicker menyatakan bahwa walfare state adalah "a state which benefits its citizen in accordance with certain set of principles,' from cradle to grave' Fungsi Negara semacam itulah yang menjadi keharusan bagi peran kontekstual negara-negara modern.

2. Jimly Assidiqie menyatakan bahwa negara kesejahteraan mempunyai konsep dimana negara dituntut untuk memperluas tanggung jawabnya kepada masalah-masalah sosial ekonomi yang dihadapi rakyat banyak.

3. Pada saat perumusan UUD 1945, Mohammad Yamin mengatakan: "......Bahwa Negara yang akan dibentuk itu hanya semata-mata untuk seluruh rakyat, untuk kepentingan seluruh bangsa yang akan berdiri kuat di dalam negara yang menjadi kepunyaannya", lebih lanjut disebutkan: "Kesejahteraan rakyat yang menjadi dasar dan tujuan Negara Indonesia merdeka ialah pada ringkasnya keadilan masyarakat atau keadilan sosial."12

4. Utrecht sejak negara turut serta secara aktif dalam pergaulan kemasyarakatan, maka lapangan pekerjaan pemerintah makin luas. Administrasi Negara diserahi kewajiban untuk menyelenggarakan kesejahteraan umum (bestuurszorg).

5. Bagir Manan menyebutkan bahwa dimensi sosial ekonomi dari negara berdasar atas hukum adalah berupa kewajiban negara atau pemerintah untuk mewujudkan dan menjamin kesejahteraan sosial (kesejahteraan umum) dalam suasana sebesar-besarnya kemakmuran menurut asas keadilan sosial bagi seluruh rakyat Indonesia. Dimensi ini secara spesifik melahirkan paham negara kesejahteraan (verzorgingstaat, welfare state). ${ }^{13}$

${ }^{11}$ W. Riawan Tjandra, Hukum Administrasi Negara, (Yogyakarta: Penerbit Universitas Atma Jaya, 2008) h.7-8.

12 Ridwan HR, Hukum Administrasi Negara, (Jakarta:PT.Rajagrafindo Persada, 2011), cetakan ke-7, h.18.

${ }^{13}$ Bagir Manan, Pemikiran Negara Berkonstitusi di Indonesia, makalah pada Temu Ilmuah Nasional, Fakultas Hukum Universitas Padjajaran, Bandung, 6 April 1999, h.2. 
Sjachran Basah mengatakan Indonesia ini tergolong sebagai negara kesejahteraan karena tugas pemerintah tidaklah semata-mata hanya di bidang pemerintahan saja, melainkan harus juga melaksanakan kesejahteraan sosial dalam rangka mencapai tujuan Negara yang dijalankan melalui pembangunan nasional. ${ }^{14}$

Menurut Esping-Andersen, negara kesejahteraan bukanlah satu konsep dengan pendekatan baku. Negara kesejahteraan lebih sering ditenggarai dari atribut-atribut kebijakan pelayanan dan transfer sosial yang disediakan oleh negara (pemerintah) kepada warganya seperti pelayanan pendidikan, transfer pendapatan, pengurangan kemiskinan, sehingga keduanya (negara kesejahteraan dan kebijakan sosial) sering diidentikkan. Hal itu tidak tepat karena kebijakan sosial tidak mempunyai hubungan implikasi dengan negara kesejahteraan. Kebijakan sosial bisa diterapkan tanpa keberadaan negara kesejahteraan, tetapi sebaliknya negara seperti ini selalu membutuhkan kebijakan sosial untuk mendukung keberadaannya. ${ }^{15}$

Pada dasarnya negara kesejahteraan mengacu pada peran negara yang aktif mengelola dan mengorganisasi perekonomian, yang di dalamnya, mencakup tanggung jawab negara untuk menjamin ketersediaan pelayanan kesejahteraan dasar dalam tingkat tertentu bagi warganya.

Secara umum suatu negara bisa digolongkan sebagai negara kesejahteraan jika mempunyai empat pilar utama yaitu; 1) social citizenship, 2) full democracy,3) modern industrial relation system, dan 4) right to education and the expansion of modern mass education system. ${ }^{16}$ Keempatnya ini dimungkinkan dalam negara kesejahteraan karena negara memperlakukan penerapan kebijakan sosial sebagai penganugerahan hak-hak sosial kepada warganya.

\footnotetext{
${ }^{14}$ Sjachran Basah, Eksistensi dan Tolak ukur Badan Peradilan Administrasi di Indonesia, (Bandung: Alumni, 1985), h.2-3

${ }^{15}$ S. Kuhnle dan SEO Hort, The Developmental Welfare State in Scandinavia; Lesons for the Developing World (UNRISD), 2004, hal: 10 atau lihat juga dalam Darmawan Triwibowo dan Sugeng Bahagijo, Mimpi Negara Kesejahteraan, Op.Cit, hal: 11 dan Juniarso Ridwan \& Ahmad Sodik Sudrajat, Hukum Administrasi Negara dan Kebijakan Pelayan Publik, (Bandung: Nuansa, 2009), h.53

16 Lihat Qs Saba: 15 dan Juniarso Ridwan \& Ahmad Sodik Sudrajat, Hukum Administrasi Negara dan Kebijakan Pelayan Publik, (Bandung: Nuansa, 2009), h.54
} 
Hak sosial ini mendapatkan jaminan selayaknya hak atas property serta diberikan berdasar basis kewargaan dan bukan atas dasar kinerja atau kelas. ${ }^{17}$

Negara kesejahteraan berusaha membebaskan rakyatnya dari ketergantungan pada mekanisme pasar untuk mendapatkan kesejahteraan (dekomodifikasi) dengan menjadikannya sebagai hak setiap warga yang bisa diperoleh melalui perangkat kebijakan sosial yang disediakan negara. Dalam rangka kesejahteraan, adanya system kesejahteraan sebagai hak sosial warga harus diimbangi oleh dua hal yang saling terkait yaitu: pertumbuhan ekonomi dan kesempatan kerja. Pada satu sisi, hak sosial tidak seharusnya menjadi disinsetif bagi warga untuk terlibat dalam pasar tenaga kerja, sehingga negara harus menerapkan kebijakan ketenagakerjaan yang aktif guna mendorong partisipasi penuh warga dalam pasar tenaga kerja. Di sisi lain, luasnya basis hak sosial membutuhkan sumber pembiayaan yang memadai melalui system perpajakan yang kuat, yang hanya dimungkinkan melalui pertumbuhan ekonomi dengan peran aktif pemerintah pemerintah didalamnya. Segi tiga antara peran negara dalam pertumbuhan ekonomi-jaminan hak sosial kebijakan aktif tenaga kerja adalah karakteristik kunci dari suatu negara kesejahteraan. ${ }^{18}$

\section{Konsep Welfare State di Indonesia}

Para pendiri negara Indonesia telah menyepakati bahwa salah satu tujuan didirikannya negara Indonesia adalah agar keadilan dan kemakmuran bangsa Indonesia bisa diwujudkan. Unsur-unsur welfare state ini telah dimasukkan ke dalam dasar negara Indonesia (Pancasila dan UUD 1945) pada saat persiapan rapat pembahasan persiapan dan paska kemerdekaan negara Indonesia. Pembukaan UUD 1945 yang memuat rumusan tujuan negara Indonesia dan juga Pancasila menyatakan bahwa negara Indonesia dibentuk “... untuk melindungi segenap bangsa Indonesia dan seluruh tumpah darah Indonesia dan untuk memajukan kesejahteraan umum, mencerdaskan kehidupan bangsa, dan ikut melaksanakan ketertiban dunia ... dengan berdasar kepada Ketuhanan yang maha esa, kemanusiaan yang adil dan beradab, persatuan Indonesia, dan kerakyatan yang dipimpin oleh hikmat

17Juniarso Ridwan \& Ahmad Sodik Sudrajat, Hukum Administrasi Negara dan Kebijakan Pelayan Publik, h. 54

${ }^{18}$ Juniarso Ridwan \& Ahmad Sodik Sudrajat, Hukum Administrasi Negara dan Kebijakan Pelayan Publik, h. 54 
kebijaksaan dalam permusyawaratan/perwakilan serta dengan keadilan sosial bagi seluruh rakyat Indonesia."19

Rumusan dasar ideologi welfare state tadi ("memajukan kesejahteraan umum" dan sila kelima Pancasila "keadilan sosial bagi seluruh rakyat Indonesia") kemudian dimanifestasikan ke dalam batang tubuh konstitusi negara Indonesia untuk dijadikan pedoman hidup berbangsa dan penyelenggaraan kenegaraan. Dalam Pasal 34 UUD 1945 pra amandemen, negara menyatakan bertanggung jawab untuk memelihara fakir miskin dan anak-anak terlantar. Pasca amandemen keempat, tugas negara di bidang kesejahteraan sosial ini diperluas dengan tambahan tanggung jawab untuk mengembangkan sistem jaminan sosial dan memberdayakan kelompok masyarakat miskin, serta memberikan pelayanan kesehatan dan fasilitas pelayanan umum bagi rakyatnya. ${ }^{20}$

Menurut ahli Pancasila, sila kelima Pancasila tidak dimaksudkan untuk membuat Indonesia menjadi negara sosialis ataupun liberal dimana eksploitasi individu oleh individu lain atau oleh negara boleh terjadi. ${ }^{21}$ Ini sejalan dengan maksud para pendiri Indonesia ketika mengusulkan keadilan sosial menjadi salah satu dari lima sila Pancasila yakni negara yang akan berfungsi di antara ideologi sosialisme dan liberalisme/kapitalisme dalam mencapai tujuannya. Konsekuensi dari ideologi “jalan tengah" ini adalah sektor-sektor produksi yang penting bagi negara dan yang menguasai hajat hidup orang banyak dikendalikan oleh negara. Namun, hak-hak kepemilikan secara tekhnis dilindungi oleh hukum dan pengambilan hak tersebut oleh negara harus dilakukan sesuai dengan proses hukum dengan pemberian kompensasi kepada pemilik. Mahkamah Konstitusi dalam hal ini telah mengeluarkan beberapa putusan terkait konstitusional atau tidak privatisasi BUMN sebagaimana yang terdapat dalam Undang-Undang No. 22/2001 tentang Minyak dan Gas, Undang-Undang No. 20/2002 tentang Ketenaga Listrikan, dan Undang-Undang No. 7/2004 tentang Sumber Daya Air. ${ }^{22}$

Keberadaan elemen welfare state dalam dasar negara dan jaminan pemanfaatan sektor produksi vital untuk kemakmuran rakyat belum bisa

19 Pembukaan Undang-Undang Dasar 1945, Alinea ke-IV.

20 Undang-Undang Dasar 1945, pasal 34(1-3).

21 Lihat: Musthafa Kamal Pasha, et.al., Pancasila dalam Tinjauan Historis, Yuridis dan Filosois, 2nd ed. (Yogyakarta: Citra Karsa Mandiri, 2002), h.180-181.

${ }^{22}$ Alfitri, "Ideologi Welfare State Dalam Dasar Negara Indonesia", dalam Jurnal Konstitusi Volume 9 Nomor 3 (Jakarta: Mahkamah Konstitusi, 2012), h.458-459. 
dijadikan landasan untuk menyimpulkan bahwa Indonesia adalah negara dengan model institutional welfare state. Sejak berdirinya negara Indonesia, belum ada pendekatan yang jelas terhadap model kesejahteraan/keadilan sosial apa yang akan dianut. Dalam rapat Panitia Persiapan Kemerdekaan Indonesia dua hari pasca proklamasi kemerdekaan, para pendiri bangsa memaknai konsep kesejahteraan/keadilan sosial antara lain melalui pendirian Departemen Kemakmuran yang salah satunya bertugas untuk mengurusi makanan dan keperluan rakyat, dan Departemen Sosial untuk mengurusi fakir miskin. Dalam risalah sidang pada tanggal 19 Agustus 1945 tersebut tersirat bahwa Departemen Kemakmuran diperlukan untuk mengurusi makanan dan kebutuhan rakyat (voedsel-voorziening) di masa peperangan dan paska peperangan saat itu..$^{23}$ Karena sebagian anggota sidang beranggapan bahwa ruang lingkup Departemen Kemakmuran sangat besar serta urusan makanan dan kebutuhan rakyat bersifat sementara, ini kemudian menimbulkan perdebatan tentang perlu tidaknya satu departemen khusus untuk mengurusi kebutuhan rakyat di bawah Departemen Sosial dan juga kemana urusan kesejahteraan rakyat lainnya seperti kesehatan akan ditangani..$^{24}$

Konsep Negara hukum untuk mencapai Negara kesejahteraan secara implisit terkandung dalam UUD 1945 terutama bab XIV tentang kesejahteraan sosial dan pembukaan UUD 1945 dalam alinea 4 tercermin tujuan dari Negara Indonesia adalah Negara melindungi segenap bangsa dan seluruh tumpah darah Indonesia, memajukan umum, mencerdaskan kehidupan bangsa, dan ikut melaksanakan ketertiban dunia berdasarkan kemerdekaan, perdmaian abadi, dan keadilan sosial.

Konstitusional Negara Indonesia menganut prinsip Negara hukum yang dinamis atau "welfare state" karenanya tugas pemerintah sangat luas, pemerintah harus memberikan perlindungan kepada masyarakat di segala bidang, karenanya pemerintah dalam menjalankan tugasnya harus melakukan Freies Ermessen yaitu kewenangan untuk turut serta dalam kegiatan bermasyarakat untuk mencapai tujuan Negara yaitu kesejahteraan sosial. Contohnya: Melakukan pengaturan dalam kegiatan masyarakat

${ }^{23}$ Lihat: Risalah Sidang UUD 1945.

${ }^{24}$ Alfitri, "Ideologi Welfare State Dalam Dasar Negara Indonesia", dalam Jurnal Konstitusi Volume 9 Nomor 3, (Jakarta: Mahkamah Konstitusi, 2012), h. 458-459. 
dengan memberi izin atau melakukan pencabutan atas hak-hak warga Negara tertentu karena diperlukan oleh umum. ${ }^{25}$

Konsep Negara kesejahteraan merupakan wujud dari Negara hukum yang mempunyai ciri: Asas Legalitas, Asas Persamaan dalam Hukum, Peradilan yang bebas. ${ }^{26}$ Dalam menjalankan tugasnya pemerintah Indonesia harus menjaga segala tindakannya agar berada dibawah naungan ketentuan hukum yang berlaku, karena itu setiap campur tangan penguasa yang diberi izin, hal ini bertujuan untuk:

1. Menjaga ketertiban masyarakat

2. Mengatur kehidupan masyarakat

3. Menyelesaikan atau mencegah konflik atau sengketa

4. Menegakkan keamanan dan ketertiban. ${ }^{27}$

Adanya campur tangan negara terhadap kehidupan sosial masyarakat, mengakibatkan jangkauan kerja pemerintah semakin luas, terlebih lagi tidak semua kehidupan masyarakat diatur dalam ketentuan perundang-undangan. Itu artinya, bagi negara yang dalam hal ini adalah administrasi negara, memiliki suatu konsekuensi yang khusus. Di dalam pembukaan UUD 1945 untuk mewujudkan negara kesejahteraan telah diamanatkan bahwa:28 1). Negara berkewajiban memberikan perlindungan kepada segenap bangsa (warga negara) Indonesia dan seluruh wilayah teritorial Indonesia. 2). Negara berkewajiban memajukan kesejahteraan umum. 3). Negara berkewajiban mencerdaskan kehidupan bangsa.

Berkaitan dengan konsep negara kesejahteraan yang merupakan revisi dari konsep negara pasif, Asshiddiqie menguraikan: ${ }^{29}$

Dalam konsep negara kesejahteraan ini, negara dituntut untuk memperluas tanggung jawabnya kepada masalah-masalah sosial ekonomi yang dihadapi

${ }^{25}$ Anggriani Jum, Hukum Administrasi Negara, (Yogyakarta: Graha Ilmu, 2012), h. 40-41.

${ }^{26}$ Anggriani Jum, Hukum Administrasi Negara, h. 41.

${ }^{27}$ Anggriani Jum, Hukum Administrasi Negara, h. 42.

${ }^{28}$ Juniarso Ridwan \& Ahmad Sodik Sudrajat, Hukum Administrasi Negara dan Kebijakan Pelayan Publik, h. 56

${ }^{29}$ Jimly Asshiddiqie, Gagasan Kedaulatan Rakyat Dalam Konstitusi dan Pelaksanaannya di Indonesia, Pergeseran Keseimbangan Antara Individualisme dan Kolektivisme dalam Kebijakan Demokrasi Politik dan Demokrasi Ekonomi Selama Tiga Masa Demokrasi, 1945-1980an, (Jakarta: Ichtiar Baru van Hoeve, 1994, 223). Lihat juga: W. Riawan Tjandra, Hukum Administrasi Negara, h.9. 
rakyat banyak. Perkembangan inilah yang memberikan legalisasi bagi 'negara intervesionis' abad ke-20.Negara justru perlu dan bahkan harus melakukan intervensi dalam berbagai masalah sosial dan ekonomi untuk menjamin terciptanya kesejahteraan bersama dalam masyarakat.

Dengan intervensi ini, fungsi negara juga meliputi kegiatan-kegiatan yang sebelumnya berada diluar jangkauan fungsi negara, seperti memperluas ketentuan pelayanan sosial kepada individu dan keluarga dalam hal-hal khusus, seperti 'social security', kesehatan, kesejahteraan sosial, pendidikan dan pelatihan serta perumahan. Di samping itu, kegiatan intervensi negara itu juga meluas sampai pada pengaturan terhadap berbagai aktivitas masyarakat, baik secara individual maupun badan-badan kolektif (corporate bodies) untuk maksud kondisi hidup dan kehidupan individu dan kelompok penduduk secara relatif cepat.

Apabila semula negara hanya dipandang sebagai instrument of power, maka mulai timbul aliran-aliran yang menganggap negara sebagai agency of service.Maka timbullah konsep welfare state yang terutama memandang manusia tidak hanya sebagai individu, akan tetapi juga sebagai anggota atau warga dari kolektiva dan bahwa manusia bukanlah semata-mata merupakan alat kepentingan kolektiva akan tetapi juga untuk tujuan dirinya sendiri. ${ }^{30}$

Muchsan meyakini bahwa negara RI berdasarkan UUD 1945 termasuk negara yang bertipe welfare. Sesuai dengan UUD 1945, menurut Muchsan fungsi negara RI dapat dijabarkan sebagai berikut: ${ }^{31}$

1. Fungsi pertama adalah tugas keamanan, pertahanan, dan ketertiban (defence, security, and protectional function). Penjabaran fungsi ini negara harus mempertahankan apabila ada serangan dari luar dan rongrongan atau pemberontakan dari dalam, pencegahan terhadap pencurian kekayaan di lautan serta kekayaan alam lainnya, baik di laut maupun di udara, pelanggaran wilayah oleh angkatan perang asing, dan sebagainya. Termasuk juga dalam fungsi ini perlindungan terhadap kehidupan, hak milik, dan hak-hak lainnya sesuai yang akan diatur dalam peraturan perundang-undangan.

30 Soejono Soekanto, Beberapa Permasalahan Hukum Dalam Kerangka Pembangunan di Indonesia, (Jakarta: UI Press, 1983), h. 68. Lihat juga: W. Riawan Tjandra, Hukum Administrasi Negara, h.11-12.

${ }^{31}$ Muchsan Sistem Pengawasan Terhadap Perbuatan Aparat Pemerintah dan Pengadilan Tata Usaha Negara di Indonesia, (Yogyakarta: Liberty, 1992), h.8. Lihat juga: W. Riawan Tjandra, Hukum Administrasi Negara, h.17-18 
2. Fungsi kedua adalah tugas kesejahteraan atau welfare function. Tugas inipun dalam arti yang seluas-luasnya, termasuk social service dan social welfare, seperti bantuan bencana alam, kemiskinan, pengangguran, penentuan upah minimum, bantuan kesehatan, panti asuhan, dan lain-lain. Yang jelas seluruh kegiatan yang ditunjukkan terwujudnya kesejahteraan masyarakat serta keadilan sosial bagi seluruh bangsa Indonesia.

3. Fungsi ketiga adalah tugas pendidikan (educational function). Inipun harus ditafsurkan dalam arti yang seluas-luasnya. Termasuk dalam fungsi ini misalnya tugas untuk penerangan umum, nation and character building, peningkatan kebudayaan, dan lain-lain.

4. Fungsi keempat adalah tugas untuk mewujudkan ketertiban serta kesejahteraan dunia (world peace and human welfare) dalam arti yang luas pula. Dalam politik bebas aktif, Negara RI ikut menciptakan kedamaian yang kekal dan abadi bagi kehidupan manusia pada umumnya.

Selanjutnya, Muchsan ${ }^{32}$ menguraikan bahwa UUD 1945 menciptakan keseimbangan serta keterpaduan antara fungsi regular dan fungsi pembangunan, yang semakin memperluas kewajiban negara.Negara dengan kewenangannya mengatur dan mengarahkan segala aspek kehidupan masyarakat, guna mewujudkan keadilan sosial bagi seluruh bangsa Indonesia tanpa kecuali, sehingga disebut sebagai negara hukum sosial (sociale rechtsstaat).Terdapat 2 konsekuensilogis yang muncul dalam kehidupan negara hukum sosial, yaitu: ${ }^{33}$

Pertama; Adanya intervensi atau campur tangan negara yang cukup luas terhadap aspek kehidupan masyarakat. Campur tangan ini dituntut demi terciptanya kesejahteraan masyarakat yang merata, bukan kesejahteraan menurut filsafat liberal. Dengan adanya campur tangan ini, dapat dihindari adanya free fight liberalism yang hanya akan menguntungkan pihak yang kuat saja. Campur tangan ini diwujudkan dalam bentuk pengaturan-pengaturan serta pengarahan-pengarahan dari pihak negara terhadap kehidupan

32 Muchsan, Sistem Pengawasan Terhadap Perbuatan Aparat Pemerintah dan Pengadilan Tata Usaha Negara di Indonesia, (Yogyakarta: Liberty, 1992), h. 8-9.

33 Muchsan, Sistem Pengawasan Terhadap Perbuatan Aparat Pemerintah dan Pengadilan Tata Usaha Negara di Indonesia, h.9-10. Lihat juga: W. Riawan Tjandra, Hukum Administrasi Negara, h.18-19. 
masyarakat. Dengan demikian gerak kehidupan masyarakat akan searah dengan pembangunan yang dilaksanakan oleh negara. Menurut Irving Swedlow, campur tangan pemerintah dalam proses pembangunan terhadap perkembangan kehidupan masyarakat dapat dilakukan dengan lima macam cara, yakni:

a). Operasi langsung (direct operation). Dalam hal ini pemerintah langsung aktif melakukan kegiatan yang dimaksudkan: Misalnya dalam penciptaan keluarga kecil sejahtera, pemerintah melaksanakan KB. Dalam kehidupan ekonomi, pemerintah langsung membentuk dan mengarahkan bentuk-bnetuk koperasi.

b). Pengendalian langsung (direct control). Langkah pemerintah diwujudkan dalam bentuk penggunaan perijinan, lisensi, penjatahan, dan lain sebagainya.Sudah barang tentu lembaga pemberi ijin harus mendapatkan kewenangan untuk itu terlebih dahulu berdasarkan kaidah hukum yang berlaku.Oleh karenanya dalam hal ini dituntut adanya pembagian kewenanngan (distribution of authority) yang jelas dan tegas, demi adanya kepastian hukum yang tinggi.

c). Pengendalian tidak langsung (indirect control). Lewat peraturan perundang-undangan yang ada, pemerintah dapat menetapkan persyaratanpersyaratan yang harus dipenuhi untuk terlaksananya kegiatan tertentu. Misalnya penggunaan devisa tertentu diperbolehkan asal untuk pembelian barang-barang tertentu.

d). Pemengaruhan langsung (direct influence). Intervensi ini dilakukandengan cara persuasi, pendekatan ataupun nasehat, agar supaya anggota masyarakat tertentu mau bertingkah laku seperti yang dikehendaki oleh pemerintah. Misalnya, dengan pemberian penyuluhan agar masyarakat petani mamu berkoperasi, malakukan transmigrasi, dan sebagainya.

e). Pemengaruhan tak langsung (indirect influence). Ini merupakan bentuk involvement yang paling ringan, tetapi tujuannya untuk menggiring masyarakat agar berbuat seperti yang dikehendaki oleh pemerintah.Misalnya, pemberian informasi, penjelasan kebijaksanaan pemerintah, pemberian penghargaan kepada para teladan di bidangnya masing-masing, dan sebagainya.

Kedua; Digunakannya diskresi dalam penyelenggaraan pemerintahan. Perkembangan hukum administrasi modern dalam apa yang oleh de Haan, 
dkk disebut sebagai negara hukum sosial (sociale rechtsstaat) dapat dilukiskan berikut ini:

\section{Teori Welfare State Dalam Prespektif Islam dan Agama Lain}

Welfare State dalam islam bukan sekedar dasar hukumnya berbeda dari barat yang hanya mengutamakan akal. Justru islam juga mengakui akal tetapi tidak meninggalkan wahyu. Welfare State dalam konsep islam dapat dipahami sebagai tanggung jawab Negara dalam kesejahteraan masyarakat dari aspek kebutuhan dasar hidup/basic needs) maupun rohaniyah/segi material maupun spiritual.

Secara garis besar pelaksanaan kesejahteraan sosial dalam islam meliputi kesejahteraan individu dan kesejahteraan masyarakat yang terdiri dari:

a. Meningkatkan nilai-nilai spiritual islam terhadap individu dan juga masyarakat

b. Pemenuhan kebutuhan dasar hidup (basic needs) meliputi 6 hal, yang oleh Umar Chapra: 1). Latihan dan pendidikan sesuai bakat yang dimiliki; 2). Tersedianya pekerjaan sesuai dengan bakat, kemampuan dan ketrampilannya maupun kebutuhan masyarakat; 3). Cukup makanan dan pakaian; 4). Rumah yang nyaman; 5). Kesehatan lingkungan pada umumnya dikombinaskan dengan fasilitas kesehatan yang cocok dan 6). Pemenuhan fasilitas transport yang memudahkan pekerjaan ke tempat kerja maupun mambawa produk mereka ke pasar.

Prinsip kesejahteraan dalam pandangan negara hukum Islam pada hakikatnya memiliki tujuan untuk mewujudkan keadilan sosial dan ekonomi bagi masyarakat, yang mana ini dibebankan kepada penyelenggara negara dan masyarakat. Negara memiliki kewajiban untuk memperhatikan dua macam kebutuhan, yaitu kebutuhan materiil dan kebutuhan spiritual. Untuk mewujudkan prinsip kesejahteraan tersebut, Al-Qur'an telah merumuskan dengan kalimat "baldatun thayibatun wa rabbun ghaffur"34, yaitu suatu negara yang sejahtera di bawah ridha Allah. Negara berkewajiban mengatur dan mengalokasikan dana dalam jumlah yang cukup untuk keperluan jaminan sosial bagi mereka yang memerlukannya. Dengan kata lain, negara

\footnotetext{
34 Muhammad Tahir Azhary, Negara Hukum, (Jakarta: Bulan Bintang, 1992) hal: 107
} 
berkewajiban pula menyediakan sarana dan prasarana sebagai penunjang terciptanya suatu negara yang sejahtera. ${ }^{35}$

Menurut Tahir Azhary, ${ }^{36}$ prinsip kesejahteraan untuk mewujudkan keadilan sosial dan ekonomi bagi masyarakat. Keadilan sosial ini mencakup pemenuhan kebutuhan materil (kebendaan) dan kebutuhan spiritual bagi seluruh rakyat. Tugas ini dibebankan kepada penyelenggara negara serta masyarakat dan untuk mewujudkannya dituntut atas ditegakkannya prinsip lain sebagai prasyarat seperti prinsip keadilan, persamaan, peradilan bebas, dan perlindungan hak asasi manusia. ${ }^{37}$

Implementasi prinsip kesejahteraan diarahkan untuk mencapai apa yang disebut oleh Musthafa as-Siba'I sebagai system masyarakat islam dengan ciri-ciri khususnya. As-Siba' ${ }^{\prime}{ }^{38}$ menyebutkan beberapa karakteristik system masyarakat islam: ${ }^{39}$

a. System masyarakat islam bukan berarti masyarakat zahid (menghindari dunia) dan darwisy (sufi pengembara) yang memilih hidup melarat menurut paham sufi. System masyarakat Islam adalah system kehidupan yang berdaya maju, bergerak, dan aktif untuk membangun satu masyarakat modern.

b. System masyarakat Islam, dengan pengakuannya atas 5 hak asasi dan perundang-undangan untuk jaminan sosial, memiliki daya gerak untuk membasmi kemelaratan, kebodohan dan perasaan rendah diri.

c. System masyarakat Islam cocok untuk kaum Muslim dan non-Muslim, karena dasar dan hak dalam system ini merata ke semua penduduk tanpa terkecuali.

d. System masyarakat Islam mengikutsertakan rakyat bersama dengan pemerintah dalam melaksanakan jaminan sosial.

\footnotetext{
${ }^{35}$ Juniarso Ridwan \& Ahmad Sodik Sudrajat, Hukum Administrasi Negara dan Kebijakan Pelayan Publik, h. 56

${ }^{36}$ Musthafa as-Siba'I, Sistem Masyarakat Islam, (Jakarta: Pustaka Hidayah, 1987) hal: $181-182$

37Juniarso Ridwan \& Ahmad Sodik Sudrajat, Hukum Administrasi Negara dan Kebijakan Pelayan Publik, h. 57

${ }^{38}$ Ridwan HR, Figh Politik, Gagasan, Harapan dan Kenyataan, (Yogyakarta: UII Press, 2007), hal: 63

${ }^{39}$ Juniarso Ridwan \& Ahmad Sodik Sudrajat, Hukum Administrasi Negara dan Kebijakan Pelayan Publik, h. 57
} 
e. System masyarakat Islam mudah dibentuk, tidak kaku, dan bisa dipraktikan setiap waktu sesuai dengan perkembangan dan kemajuan zaman.

Salah satu tugas pemerintah adalah perwujudan kesejahteraan bagi masyarakat. Dalam perkembangan tugas pemerintah, negara menempatkan pemerintah selaku pihak yang dilekati dengan kewajiban untuk mewujudkan kesejahteraan rakyat, yang dikenal dengan negara kesejahteraan (welfare state). Dalam ajaran Islam terdapat norma dan nilai yang mengarahkan terwujudnya kesejahteraan bagi masyarakat seperti larangan menumpukkan kekayaan pada sekelompok orang tertentu, anjuran menjadi seorang dermawan, pengaturan tentang zakat, infaq dan shadaqah. ${ }^{40}$

\section{Welfare State Dalam Ajaran Agama Lain}

Ajaran agama juga memberikan basis etnis yang kuat bagi perkembangan konsep negara kesejahteraan. Seperti yang diuraikan oleh Manou, perbedaan karakter ajaran agama yang dominan di suatu negara juga mempengaruhi format rezim kesejahteraan yang berkembang di suatu negara, khususnya di negara Eropa. Sebagai contoh Esping-Andersen yang mengungkapkan tentang kuatnya pengaruh doktrin sosial Katolik dalam rezim kesejahteraan konservatif. ${ }^{41}$

Pengaruh ini bisa dilacak dari ajaran sosial gereja yang dikeluarkan sejak abad ke-19 di mana hal-hal baru tentang keadaan kaum buruh, yang merupakan teks Ensiklik Paus Leo XIII pada tahun 1891, merupakan teks yang dinilai mempunyai pengaruh besar bagi perkembangan system jaminan sosial di Eropa pada abad ke-20. Secara umum, teks Ensiklik tersebut merupakan respon gereja terhadap perkembangan sosial yang terjadi setelah Revolusi Industri, khususnya terhadap manguatnya sosialisme dan kecenderungan pertentangan antar kelas sosial. Teks itu secara eksplisit juga

${ }^{40}$ Sjahran Basah, Rangkuman Sari prkuliahan Ilmu Negara, (disusun oleh Tatang Basah), Pada Grafika Unit II, Bandung, hal: 99-104

${ }^{41}$ Juniarso Ridwan \& Ahmad Sodik Sudrajat, Hukum Administrasi Negara dan Kebijakan Pelayan Publik, h. 54 
menunjukkan bagaimana negara berperan. Di antara butir-butir kebijakan tersebut adalah:42

a. Tugas utama dari penguasa ialah mengarahkan seluruh system perundangan dan lembaga untuk memberikan bantuan pada khalayak maupun kepada golongan khas, juga kepemimpinan negara mengusahakan agar struktur dan fungsi administrasi negara bisa meningkatkan kesejahteraan umum dan perseorangan (hak negara untuk campur tangan).

b. Tidak masuk akal ketika memperhatikan satu lapisan masyarakat, sedang lapisan yang lain diabaikan. Pemerintah serius menjamin kehidupan dan kesejahteraan penduduk yang miskin, dan pengingkaran kewajiban itu berarti pelanggaran terhadap keadilan. Yang diutamakan adalah menjaga tegaknya keadilan distributif dengan tanpa memihak (perhatian terhadap kesejahteraan umum).

c. Pemerintah harus campur tangan ketika kepentingan umum dirugikan atau terancam bahaya, karena itu satu-satunya jalan untuk mencegah kejahatan (prinsip campur tangan negara).

Selain butir-butir tentang peran negara, teks Ensiklik ini juga menyoroti pentingnya atas pemenuhan hak kesejahteraan kaum buruh seperti misalnya kondisi kerja yang layak, hak menerima upah layak, serta hak kodrati untuk membentuk serikat. ${ }^{43}$

\section{Relevansi Welfare State dan Hukum Administrasi Negara}

Perkembangan konsep negara hukum di masa sekarang telah membawa kepada konsep negara kesejahteraan yang erat kaitannya dengan peranan hukum administrasi negara. Hal ini dikarenakan dalam konsep negara kesejahteraan peran negara dan pemerintah semakin dominan.

Tujuan yang ingin dicapai adalah bagaimana memberikan kesejahteraan bagi warganya. Agar tujuan ini bisa dicapai maka dalam menggerakkan roda penyelenggaraan pemerintahan diperlukan perangkat

42Juniarso Ridwan \& Ahmad Sodik Sudrajat, Hukum Administrasi Negara dan Kebijakan Pelayan Publik, h. 54-55

43Juniarso Ridwan \& Ahmad Sodik Sudrajat, Hukum Administrasi Negara dan Kebijakan Pelayan Publik, h. 55 
yang sesuai dengan tujuan dan wewenang masing-masing. Pemberian wewenang itu termasuk dalam ruang lingkup hukum administrasi negara. Dengan demikian secara akademik tepat apa yang dikemukakan oleh Van Vollenhoven seperti yang dikutip oleh Moch Koesnardi dan Hermaily Ibrahim. ${ }^{44}$

“Badan-badan negara tanpa tata negara itu lumpuh bagaikan sayap, karena badan-badan itu tidak mempunyai wewenang sehingga keadaannya tidak menentu. Sebaliknya badan-badan negara tanpa adanya hukum administrasi negara menjadi bebas tanpa batas, karena mereka dapat berbuat menurut apa yang mereka inginkan."

Agar dapat menjalankan tugas-tugas itu dengan baik, maka administrasi negara memerlukan kemerdekaan untuk dapat bertindak atas inisiatif sendiri, terutama dalam penyelesaian soal-soal genting yang timbul dengan sekonyong-konyong dan yang peraturan penyelenggaraannya belum ada atau belum dibuat oleh lembaga yang berkompeten. Pemberian kewenangan atau kemerdekaan kepada administrasi negara dalam system hukum administrasi negara sering dikenal dengan Freise Ermessen atau discretionary power, suatu istilah yang mengandung kewajiban dan kekuasaan yang luas. Kewajiban adalah tindakan yang harus dilakukan, sedangkan kekuasaan yang luas itu mengindikasikan adanya kebebasan memilih, melakukan atau tidak melakukan tindakan. ${ }^{45}$

Negara hukum adalah suatu negara yang menentukan cara bagaimana hak asasi manusia dilindungi. Cara untuk melindungi hak ini berarti pula masyarakat siapakah yang berhak menentukan peraturan itu dan bagaimana peraturan itu dilaksanakan. Yang berhak menentukan peraturan dan perundang-undangan itu adalah rakyat karena mereka yang langsung berkepentingan, sehingga negara hukum menjadi system yang wajar dalam negara demokrasi. ${ }^{46}$

${ }^{44}$ Esping-Andersen, dalam Darmawan Triwibowo dan Sugeng Bahagijo, Mimpi Negara Kesejahteraan, (Jakarta, LP3ES, 2006) hal 8 dan Juniarso Ridwan \& Ahmad Sodik Sudrajat, Hukum Administrasi Negara dan Kebijakan Pelayan Publik, h. 53.

45Juniarso Ridwan \& Ahmad Sodik Sudrajat, Hukum Administrasi Negara dan Kebijakan Pelayan Publik, h. 58

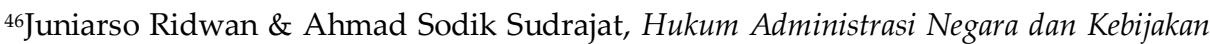
Pelayan Publik, h. 60. 
Berdasarkan uraian tersebut maka negara hukum pada masa lalu mengikat penguasa untuk tidak bertindak sebelum peraturannya ada. Apabila dikaitkan dengan hukum administrasi, maka terlihat hukum administrasi negara kurang negara kurang memiliki peranan karena pejabatnya hanya pasif serta baru bertindak jika baru ada perselisihannya di masyarakat. Dengan kata lain para pejabat hanya berperan sebagai pengemudi dengan tanpa berwenang untuk membelokkan dan menghentikan kendaraan ${ }^{47}$

Bagaimana dengan negara hukum pada masa sekarang ini? Di sini terlihat bahwa hukum administrasi negara dan aparatnya memegang peranan yang besar, karena negara memberikan kewenangan kepada penguasa untuk menyelenggarakan kepentingan dan kesejahteraan rakyat secara langsung, sehingga fungsi negara menjadi aktif. Dengan begitu, negara kesejahteraan dalam melaksanakan tugas menyejahterakan warganya merupakan sesuatu yang bersifat condition sine qua non. ${ }^{48}$

Dilihat dari sudut tertentu, dalam negara kesejahteraan tugas pemerintah dalam menyelenggarakan kepentingan umum menjadi sangat luas. Untuk itu diperlukan adanya keleluasaan untuk bergerak dalam administrasi negara sesuai kewenangan yang diberikan. Dalam kenyataannya administrasi negara dalam melaksanakan tugasnya itu terkadang melampaui batas wewenang yang ditetapkan dalam hukum administrasi negara. ${ }^{49}$

Uraian di atas memberikan pandangan, bagaimana luasnya fungsi dari administrasi negara dalam negara kesejahteraan, sehingga semakin luas pula bidang tugas yang diemban. Dalam kaitan ini, Sunaryati Hartono ${ }^{50}$ menyatakan sukar untuk dibayangkan suatu negara modern saat ini tanpa adanya hukum administrasi negara. ${ }^{51}$

Dalam konteks Indonesia, pernyataan Sunaryati Hartono ini mendapat tanggapan positif dari pemerintah, yakni dengan diundangkannya UU No.5

\footnotetext{
${ }^{47}$ Juniarso Ridwan \& Ahmad Sodik Sudrajat, Hukum Administrasi Negara dan Kebijakan Pelayan Publik, h. 60

48Juniarso Ridwan \& Ahmad Sodik Sudrajat, Hukum Administrasi Negara dan Kebijakan Pelayan Publik, h. 61

${ }^{49} J u n i a r s o$ Ridwan \& Ahmad Sodik Sudrajat, Hukum Administrasi Negara dan Kebijakan Pelayan Publik, h. 61

50 Sunaryati Hartono, Beberapa Pikiran Mengenai Suatu Peradilan Administrasi Negara di Indonesia, (Bandung: Bina Cipta, 1976), hal: 8

${ }^{51}$ Juniarso Ridwan \& Ahmad Sodik Sudrajat, Hukum Administrasi Negara dan Kebijakan Pelayan Publik, h. 61
} 
Tahun 1986 yang telah diubah dengan UU No.9 Tahun 2004 tentang Peradilan Tata Usaha Negara (PTUN). Adapun tujuannya agar terpelihara rasa keadilan masyarakat (public service terhadap warganya) bisa ditingkatkan sehingga keseimbangan antara kepentingan umum dan kepentingan individu dapat terjalin dengan sempurna. Kiranya perwujudan peradilan administrasi tersebut tidak bertentangan dan bahkan tidak akan menghambat lajunya roda pembangunan. ${ }^{52}$

\section{Penutup}

Welfare state adalah tanggung jawab negara terhadap kesejahteraan warganya. Negara kesejahteraan adalah upaya untuk melepaskan diri dari stigma UU Miskin. Itu tidak dirancang untuk masyarakat miskin; itu seharusnya menawarkan perlindungan sosial bagi semua orang, untuk mencegah orang dari menjadi miskin.

Konsep kesejahteraan negara tidak hanya mencakup deskripsi mengenai sebuah cara pengorganisasian kesejahteraan (welfare) atau pelayanan sosial (social services). Melainkan juga sebuah konsep normatif atau sistem pendekatan ideal yang menekankan bahwa setiap orang harus memperoleh pelayanan sosial sebagai haknya. Kesejahteraan negara juga merupakan anak kandung pergumulan ideologi dan teori, khususnya yang bermatra sayap kiri (left wing view), seperti Marxisme, Sosialisme, dan Sosial Demokratik. Namun demikian, dan ini yang menarik, konsep kesejahteraan negara justru tumbuh subur di negara-negara demokratis dan kapitalis, bukan di negara-negara sosialis.

Konsep negara kesejahteraan tidak hanya mencakup deskripsi mengenai sebuah cara pengorganisasian kesejahteraan (welfare) atau pelayanan sosial (socisl service). Melainkan juga sebuah konsep normatif atau system pendekatan ideal yang menekankan bahwa setiap orang harus memperoleh pelayanan sosial sebagai haknya.Negara kesejahteraan juga merupakan anak kandung pergumulan ideologi dan teori, khusunya yang bermatra sayap kiri (leftwing view), seperti Marxisme, Sosialisme, dan Sosial Demokratik. Namun demikian, dan ini yang menarik, konsep negara

52Juniarso Ridwan \& Ahmad Sodik Sudrajat, Hukum Administrasi Negara dan Kebijakan Pelayan Publik, h. 61. 
kesejahteraan justru tumbuh subur di negara-negara demokratis dan kapitalis, bukan di negara-negara sosialis.

Konsepsi negara hukum untuk mencapai negara kesejahteraan secara implisit terkandung dalam UUD 1945 terutama bab XIV tentang kesejahteraan sosial dan pembukaan UUD 1945 dalam alinea 4 tercermin tujuan dari negara Indonesia adalah Negara melindungi segenap bangsa dan seluruh tumpah darah Indonesia, memajukan umum, mencerdaskan kehidupan bangsa, dan ikut melaksanakan ketertiban dunia berdasarkan kemerdekaan, perdamaian abadi dan keadilan sosial.

\section{Pustaka Acuan}

Encyclopedia Britannica, http://www.britannica.com/print/topic/639266 (diakses 22 Sep. 14).

The Concise Oxford Dictionary of Politics. Oxford University Press 2009. Oxford Reference Online. Oxford University Press. University of Washington, http://www.oxfordreference.com.offcampus.lib.washington.edu/views/ENTR Y. html?subview=Main\&entry=t86.e1462 (diakses 22 Sep. 14).

Paul Spicker, Poverty and the Welfare State: Dispelling the Myths (London: Catalyst, 2002)

Alfitri, ideologi Welfare State dalam Dasar negara indonesia, Jurnal Konstitusi Volume 9 Nomor 3 (jakarta: Mahkamah Konstitusi, 2012)

Edi Suharto, Welfare State, 2006,

Pancasila dalam Tinjauan Historis, Yuridis dan Filosois, 2nd ed. (Yogyakarta: Citra Karsa Mandiri, 2002)

Azhary, Muhammad Tahir, Negara Hukum: Suatu Study tentang Prinsip-prinsipnya dilihat dari Segi Hukum Islam, implementasinya pada Periode Negara Madinah dan Masa Kini, Jakarta: Bulan Bintang, 1992.

Basah, Sjachran, Eksistensi dan Tolak ukur Badan Peradilan Administrasi di Indonesia, Bandung: Alumni, 1985.

Budiardjo, Miriam, Dasar-dasar Ilmu Politik, Gramedia pustaka utama, Jakarta: 2001.

G. Caroline, Hernandez, Governance, Civil Society, and Democracy, Jakarta: 1999.

HR, Ridwan, Hukum Administrasi Negara, Jakarta: PT. Rajagrafindo Persada, 2011.

Iskatrinah, "Pelaksanaan Fungsi Hukum Administrasi Negara dalam mewujudkan Pemerintahan yang Baik", http://dinulislam.blogspot.com/pelaksanaan- 
fungsi-hukum-administrasi-negara-dalam-mewujudkan-pemerintahan-yangbaik.html, diunduh pada tanggal 21 September 2013.

John, Harris (1999), "State Social Work and Social Citizenship in Britain: From Cliettelism to Consumerism" dalam The British Journal of Social Work, Vol:29, No.6.

Jum, Anggraini, Hukum Administrasi Negara, Yogyakarta: Graha Ilmu, 2012.

Manan, Bagir, Pemikiran Negara Berkonstitusi di Indonesia, makalah pada Temu Ilmuwan Nasional, Fakultas Hukum Universitas Padjajaran, Bandung, 6 April 1999.

M. Hadjon, Philipus, Hukum Tata Negara dan Hukum Administrasi sebagai instrument Hukum untuk Mewujudkan Good Governance, Jakarta: 2008.

Paul, Spicker, Social Policy: Themes and Approaches, London: Prentice hall, 1995.

Soesastro, Hadi, Governance and Indonesia's Suistainable Development. Jakarta: 1999.

Suharto, Edi, Membangun Masyarakat Memberdayakan Rakyat: Kajian Strategis Pembangunan Kesejahteraan Sosial dan Pekerjaan Sosial, Bandung: Refika Aditama, 2005.

Tjandra, W. Riawan, Hukum Administrasi Negara, Yogyakarta: Penerbit Universitas Atma Jaya, 2008.

Wasistiono, Sadu, Kapita Selekta Penyelenggaraan Pemerintahan Daerah, Bandung: Fokus Media, 2003. 